\title{
Thalassococcus halodurans gen. nov., sp. nov., a novel halotolerant member of the Roseobacter clade isolated from the marine sponge Halichondria panicea at Friday Harbor, USA
}

\author{
On On Lee, ${ }^{1}$ Mandy M. Y. Tsoi, ${ }^{1}$ Xiancui Li, ${ }^{1}$ Po-Keung Wong ${ }^{2}$ \\ and Pei-Yuan Qian ${ }^{1}$ \\ ${ }^{1}$ Coastal Marine Laboratory/Department of Biology, Hong Kong University of Science and \\ Technology, Clear Water Bay, Kowloon, Hong Kong SAR \\ ${ }^{2}$ Department of Biology, Chinese University of Hong Kong, Shatin, N. T., Hong Kong SAR
}

Correspondence

Pei-Yuan Qian

boqianpy@ust.hk
The Roseobacter clade falls within the $\alpha-3$ subgroup of the Proteobacteria and is one of the nine dominant marine clades that comprise marine microbial communities (Giovannoni \& Rappé, 2000). Members of this clade represent one of the most readily cultivated groups of marine lineages and are isolated from diverse marine environments ranging from coastal to open waters, sea floor to sea ice, in the form of free-living or particleattached cells or in association with marine phytoplankton, invertebrates or vertebrates (see review by Buchan et al., 2005 and references therein). The first genus within this clade, Roseobacter, was established in 1991, in which two

The GenBank/EMBL/DDBJ accession number for the $16 \mathrm{~S}$ rRNA gene sequence of strain UST050418-052 ${ }^{\top}$ is DO397336.

Scanning electron micrographs of cells of strain UST050418-052 ${ }^{\top}$ are available as supplementary material with the online version of this paper. species, Roseobacter litoralis and Roseobacter denitrificans, were described (Shiba, 1991). Since then, the number of species and genera described has been increasing steadily. By 2004, this clade contained 35 species with validly published names from 16 genera: Antarctobacter, Jannaschia, Ketogulonicigenium, Leisingera, Loktanella, Oceanibulbus, Oceanicola, Octadecabacter, Roseobacter, Roseovarius, Ruegeria, Sagittula, Salipiger, Silicibacter, Staleya and Sulfitobacter (Schaefer et al., 2002; Allgaier et al., 2003; Cho \& Giovannoni, 2004; Martínez-Cánovas et al., 2004; Wagner-Döbler et al., 2004; Van Trappen et al., 2004). At the time of writing, about 45 species have been described in 24 genera (Yi \& Chun, 2006). This paper deals with the description of another novel bacterial strain in the Roseobacter clade, strain UST050418-052 ${ }^{\mathrm{T}}$.

Strain UST050418-052 ${ }^{\mathrm{T}}$ was isolated from the surface of a colony of the marine sponge Halichondria panicea collected 
from Friday Harbor, San Juan Island, WA, USA, in April 2005. A freshly collected sponge colony was rinsed with autoclaved $0.22 \mu \mathrm{m}$-filtered seawater (AFSW) to remove loosely attached bacteria and its surface was then swabbed with a sterile cotton bud, which was then placed in a culture tube containing $1 \mathrm{ml}$ AFSW for subsequent bacterial isolation and purification procedures. By using the standard dilution plating technique on a marine agar medium containing $3 \mathrm{~g}$ yeast extract (Oxoid), $5 \mathrm{~g}$ peptone (Oxoid) and $12 \mathrm{~g}$ bacteriological agar (Oxoid) in 11 AFSW at $32 \%$ salinity and repeated purification and incubation at $28{ }^{\circ} \mathrm{C}$ for $48 \mathrm{~h}$, pure colonies of the strain were obtained. Unless otherwise specified, all characteristics described hereafter were based on cultures grown on marine agar under the same conditions. Pure colonies were observed under a light microscope (Leica MZ6; $\times 40$ magnification) as milky, raised and circular (1.1-1.4 $\mathrm{mm}$ in diameter) with an entire edge and a smooth surface. Gram staining was determined using light microscopy according to Smibert \& Krieg (1994) and cell morphology was examined using scanning electron microscopy (6700F; JEOL) according to Neu et al. (2001). Swimming and gliding motilities were observed under a phase-contrast light microscope (Olympus BX51; $\times 100$ magnification) after growing the strain on one-quarter-strength marine broth 2216 (Oxoid) solidified with 0.4 or $1.2 \%$ agar, respectively (Bowman, 2000). Strain UST050418-052 ${ }^{\mathrm{T}}$ appeared as Gram-negative, non-motile and ovoid-shaped cells (see Supplementary Fig. S1 available in IJSEM Online).
The nearly complete $16 \mathrm{~S}$ rRNA gene sequence of strain UST050418-052 ${ }^{\mathrm{T}}$ (1383 bp) was obtained bidirectionally with three replicates as described by Lau et al. (2004). Comparative analysis of the $16 \mathrm{~S}$ rRNA gene sequence with sequences deposited in GenBank using BLAST indicated that the strain fell within the Roseobacter clade in the $\alpha$ subgroup of the Proteobacteria and shared the highest sequence similarities, 99.6-99.8\%, with five uncharacterized Roseobacter strains (strains JL-129, JL-131, JL-132, JL135 and JL-137). The most closely related characterized relatives of UST050418-052 $2^{\mathrm{T}}$ are members of the genera Thalassobius (Arahal et al., 2005; Yi \& Chun, 2006), Phaeobacter (Martens et al., 2006), Marinovum (Martens et al., 2006) and Leisingera (Schaefer et al., 2002), with 95.0-95.8\% sequence similarity. The 16S rRNA gene sequence was aligned automatically and then manually with a database of $>30000$ already-aligned $16 \mathrm{~S}$ rRNA gene sequences using the ARB software package (Ludwig et al., 2004). Phylogenetic trees showing the relatedness of strain UST050418-052 $2^{\mathrm{T}}$ and other close members in the Roseobacter clade were then constructed using three treedrawing methods: neighbour-joining (Saitou \& Nei, 1987), maximum-likelihood (Felsenstein, 1981) and maximumparsimony (Fitch, 1971). The neighbour-joining tree showed that strain UST050418-052 $2^{\mathrm{T}}$ formed a distinct cluster with the five uncharacterized Roseobacter strains, and this cluster was distantly related to another cluster comprising the members of Thalassobius (Fig. 1). This close phylogenetic relationship was also revealed in the

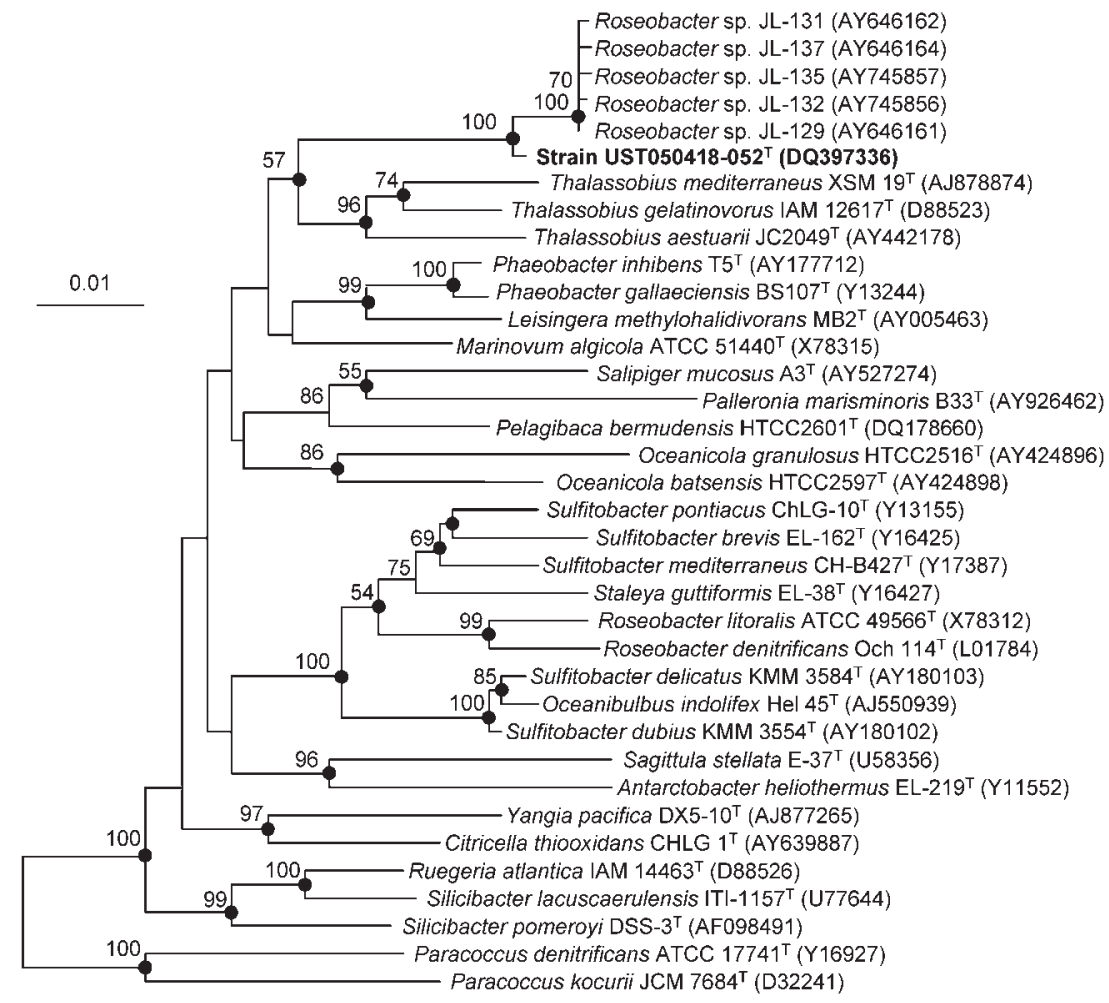

Fig. 1. Neighbour-joining tree showing the phylogenetic relationships among strain UST050418-052 ${ }^{\top}$ and related species based on 16S rRNA gene sequence comparison. Strains belonging to the genus Paracoccus were chosen as the outgroup. Filled circles indicate nodes also found in the maximumparsimony and maximum-likelihood trees. Bootstrap values over $50 \%$ (from 500 replicates) are shown at nodes. GenBank accession numbers are shown in parentheses. Bar, 1 substitution per 100 nucleotide positions. 
Table 1. Cellular fatty acid composition of strain UST050418$052^{\top}$ and members of closely related genera

Strains: 1, UST050418-052 ${ }^{\mathrm{T}}$; 2, Thalassobius aestuarii $\mathrm{JC} 2049^{\mathrm{T}}$ (data from Yi \& Chun, 2006); 3, Thalassobius gelatinovorus IAM $12617^{\mathrm{T}}$ (Arahal et al., 2005); 4, Thalassobius mediterraneus XSM19 ${ }^{\mathrm{T}}$ (Arahal et al., 2005); 5, Phaeobacter inhibens $\mathrm{T}^{\mathrm{T}}$ (Martens et al., 2006); 6, Phaeobacter gallaeciensis $\mathrm{BS}_{107^{\mathrm{T}}}$ (Martens et al., 2006); 7, Leisingera methylohalidivorans $\mathrm{MB}^{\mathrm{T}}{ }^{\mathrm{T}}$ (Martens et al., 2006); 8, Marinovum algicola ATCC $51440^{\mathrm{T}}$ (Martens et al., 2006). Values given are mean percentages of total fatty acids. -, Not detected. Fatty acids representing $<1 \%$ in all rows were excluded.

\begin{tabular}{|c|c|c|c|c|c|c|c|c|}
\hline Fatty acid & 1 & 2 & 3 & 4 & 5 & 6 & 7 & 8 \\
\hline \multicolumn{9}{|l|}{ Saturated } \\
\hline $10: 0$ & - & - & 3.5 & - & - & - & - & - \\
\hline $12: 0$ & - & - & 3.1 & - & - & - & - & - \\
\hline $16: 0$ & 13.9 & 6.8 & 2.9 & 3.0 & - & - & - & - \\
\hline $17: 0$ & 0.7 & 1.4 & - & - & 3.8 & 3.8 & 5.1 & - \\
\hline $18: 0$ & 10.9 & 3.0 & 1.9 & 1.1 & - & - & - & - \\
\hline $10: 03-\mathrm{OH}$ & - & 1.3 & 1.5 & 1.9 & 3.1 & 2.6 & 1.0 & 2.7 \\
\hline $12: 03-\mathrm{OH}$ & - & - & 5.8 & - & 1.7 & 1.9 & 1.8 & 1.2 \\
\hline $16: 02-\mathrm{OH}$ & - & 3.8 & - & - & 1.6 & 1.3 & 2.3 & 1.6 \\
\hline 19:0 cyclo & - & - & 2.3 & - & 3.1 & 3.9 & 7.0 & - \\
\hline \multicolumn{9}{|l|}{ Unsaturated } \\
\hline $12: 13-\mathrm{OH}$ & 3.2 & - & - & 4.0 & - & - & - & - \\
\hline $18: 1 \omega 9 c$ & 21.0 & - & - & - & 0.8 & 0.9 & 2.5 & 0.8 \\
\hline $18: 1 \omega 7 c$ & 37.1 & 68.0 & 68.8 & 84.6 & 2.2 & 2.1 & 2.3 & - \\
\hline $\begin{array}{l}18: 1 \omega 7 c \\
11 \text {-methyl }\end{array}$ & 3.1 & 12.0 & 7.5 & - & 0.8 & 0.9 & 2.5 & 0.8 \\
\hline $20: 2 \omega 6,9 c$ & 1.3 & - & - & - & 73.8 & 75.5 & 70.3 & 86.7 \\
\hline Summed feature $3^{\star}$ & 1.2 & - & - & - & 7.5 & 6.6 & 6.9 & 3.2 \\
\hline Summed feature $5^{\star}$ & 5.9 & - & - & - & - & - & - & - \\
\hline
\end{tabular}

${ }^{*}$ Summed feature 3 comprises iso-15:0 2-OH and/or $16: 1 \omega 7 c$. Summed feature 5 comprises $18: 2 \omega 6,9 c$ and/or anteiso- $18: 0$.

maximum-parsimony and maximum-likelihood trees (data not shown). Strain UST050418-052 ${ }^{\mathrm{T}}$ also shared the same lineage with the members of Phaeobacter, Marinovum and Leisingera. DNA-DNA hybridizations were performed by the BCCM/LMG Bacteria Collection (Laboratorium voor Microbiologie, University Gent, Gent, Belgium) as described by Ezaki et al. (1989) to determine the relatedness of UST050418-052 ${ }^{\mathrm{T}}$ with its close relatives. The strain showed DNA relatedness with Thalassobius gelatinovorus IAM $12617^{\mathrm{T}}$ and Phaeobacter inhibens $\mathrm{T}^{\mathrm{T}}$ of 9 and $7 \%$, respectively, which clearly indicated that UST050418$052^{\mathrm{T}}$ does not belong to the genera Thalassobius or Phaeobacter. These results support the conclusion that UST050418-052 ${ }^{\mathrm{T}}$ represents a novel genus within the Roseobacter clade.

Chemotaxonomic characteristics including the DNA G + C content, respiratory quinone and cellular fatty acid profile of UST050418-052 ${ }^{\mathrm{T}}$ were compared with those of members of the closely related genera Thalassobius, Phaeobacter, Marinovum and Leisingera. The DNA G $+\mathrm{C}$ content of
UST050418-052 ${ }^{\mathrm{T}}$ was determined by using an HPLC method as described in Mesbah et al. (1989) as $57.8 \pm 0.1 \mathrm{~mol} \%(n=3)$. This value is within the range of the $\mathrm{G}+\mathrm{C}$ contents (57-61 mol\%) observed among the members of closely related genera (Table 2). Extraction of respiratory quinones followed Minnikin et al. (1984) and the presence of ubiquinone Q-10, the primary isoprenoid quinone found in Thalassobius, Phaeobacter, Marinovum and Leisingera, was verified using an HPLC method according to Collins (1994). Ubiquinones extracted from Agrobacterium tumefaciens ATCC $23308^{\mathrm{T}}$ as described above served as a reference for Q-10. The cellular fatty acid profile of the strain was determined using the Sherlock Microbial Identification System (MIDI) according to the manufacturer's protocol. Strain UST050418-052 $2^{\mathrm{T}}$ had a relatively simple cellular fatty acid profile which was dominated by the monounsaturated fatty acids $18: 1 \omega 7 c$ $(37.1 \%)$ and $18: 1 \omega 9 c(21.0 \%)$, followed by the saturated fatty acids 16:0 (13.9\%) and 18:0 (10.9\%), altogether representing $82.9 \%$ of the total fatty acids (Table 1 ). The most dominant fatty acid in UST050418-052 ${ }^{\mathrm{T}}, 18: 1 \omega 7 c$, was also found in members of Thalassobius, Phaeobacter and Leisingera, but the relative proportions were drastically different; the other dominant fatty acids, $18: 1 \omega 9 c, 16: 0$ and $18: 0$, were found in very small proportions or even not detected in its close relatives (Table 1). On the other hand, the polyunsaturated fatty acid $20: 2 \omega 6,9 c$ was found in large proportions in Phaeobacter, Leisingera and Marinovum (70.3-86.7\%) but not in UST050418-052 ${ }^{\mathrm{T}}$. Results from fatty acid analysis therefore differentiated UST050418-052 ${ }^{\mathrm{T}}$ from closely related genera.

Phenotypic characteristics including growth conditions, susceptibility to antibiotics, hydrolysis of various substrates, reduction of nitrate, production of enzymes, $\mathrm{H}_{2} \mathrm{~S}$, indole and acetoin and utilization of and acid production from carbon sources were studied. The requirement for oxygen for growth was examined using the Oxoid Anaerobic System. Growth at different temperatures (4$52{ }^{\circ} \mathrm{C}$ at intervals of $\left.8{ }^{\circ} \mathrm{C}\right)$ and $\mathrm{pH}(\mathrm{pH} 5-10$ at intervals of $1 \mathrm{pH}$ unit) was monitored on marine agar for up to 10 days of incubation, while growth at different salt concentrations [0-18\%(w/v) $\mathrm{NaCl}$ at intervals of $2 \%$ ] was tested on a $1.2 \%$ agar medium containing $5 \mathrm{~g}$ peptone, $5 \mathrm{~g} \mathrm{MgCl}_{2}, 2 \mathrm{~g}$ $\mathrm{MgSO}_{4}, 1 \mathrm{~g} \mathrm{KCl}, 0.5 \mathrm{~g} \mathrm{CaCl}_{2}$ and different amounts of $\mathrm{NaCl}$, with $\mathrm{pH}$ adjusted to 7.5 using $\mathrm{KOH}$ (Isnansetyo \& Kamie, 2003). Susceptibility to streptomycin, benzylpenicillin, chloramphenicol, ampicillin, tetracycline and kanamycin (amount loaded onto paper discs ranged from 1.0 to $100.0 \mu \mathrm{g}$ per disc) was studied using standard agar discdiffusion assays according to Acar (1980). Hydrolysis of casein and cellulose was tested according to Norris et al. (1985) and Bowman (2000), respectively. Hydrolysis of Tweens 20, 40 and 80 and chitin was tested as described by Baumann \& Baumann (1981). Hydrolysis of agar, DNA and starch and production of oxidase and catalase were determined according to Smibert \& Krieg (1994). Other enzyme activities and the ability to reduce nitrate, produce 
$\mathrm{H}_{2} \mathrm{~S}$, indole and acetoin and utilize different carbon sources were assessed using commercial API 20E, API 20NE, API $50 \mathrm{CH}$ and API ZYM systems (bioMérieux) and MicroLog 3 (Biolog) according to the manufacturers' manuals. Cells for inoculating into the API 20E system were suspended in sterile seawater at $22 \%$ salinity before inoculation (MacDonell et al., 1982). Growth on glycerol, D-glucose, sucrose, D-mannitol, D-galactose, starch, D-sorbitol, Darabinose and D-melibiose as sole carbon sources was also examined on a $1.2 \%$ agar medium containing $0.2 \mathrm{~g}$
$\mathrm{NaNO}_{3}, 0.2 \mathrm{~g} \mathrm{NH}_{4} \mathrm{Cl}, 0.05 \mathrm{~g}$ yeast extract and $4 \%(\mathrm{w} / \mathrm{v})$ carbon source per litre seawater at $35 \%$ salinity (Nedashkovskaya et al., 2003). Detailed physiological and biochemical characteristics of UST050418-052 ${ }^{\mathrm{T}}$ are given in the species description.

UST050418-052 $2^{\mathrm{T}}$ differs from most of its close relatives by its ability to grow at salt concentrations higher than $9 \%$ and at $40{ }^{\circ} \mathrm{C}$ and to reduce nitrate to nitrite and its inability to utilize citrate, succinate, L-arginine and

Table 2. Phenotypic characteristics that differentiate UST050418-052 $2^{\top}$ from members of closely related genera

Strains: 1, UST050418-052 $2^{\mathrm{T}} ; 2$, Thalassobius aestuarii JC2049 ${ }^{\mathrm{T}} ; 3$, Thalassobius gelatinovorus IAM $12617^{\mathrm{T}} ; 4$, Thalassobius mediterraneus XSM19 ${ }^{\mathrm{T}}$; 5 , P. inhibens $\mathrm{T}^{\mathrm{T}}$; 6, P. gallaeciensis $\mathrm{BS} 107^{\mathrm{T}}$; 7, L. methylohalidivorans $\mathrm{MB2} 2^{\mathrm{T}} ; 8$, M. algicola ATCC $51440^{\mathrm{T}}$. Data were taken from this study, RuizPonte et al. (1998), Uchino et al. (1998), Schaefer et al. (2002), Arahal et al. (2005), Martens et al. (2006) and Yi \& Chun (2006). All strains are Gram-negative, strictly aerobic, require $\mathrm{Na}^{+}$for growth and are positive for catalase and oxidase activities. +, Positive; -, negative; ND, no data available.

\begin{tabular}{|c|c|c|c|c|c|c|c|c|}
\hline Characteristic & 1 & 2 & 3 & 4 & 5 & 6 & 7 & 8 \\
\hline DNA G $+\mathrm{C}$ content $(\mathrm{mol} \%)$ & 58 & 61 & 59 & 57 & 56 & 58 & 61 & 60 \\
\hline Cell shape & Ovoid & Ovoid & Rod & Coccoid/rod & Ovoid rod & Ovoid rod & Rod & Ovoid \\
\hline Motility & - & - & + & - & + & + & + & + \\
\hline Pigment & - & - & - & - & Brown & Brown & - & Pink \\
\hline \multicolumn{9}{|l|}{ Growth at/in: } \\
\hline $4{ }^{\circ} \mathrm{C}$ & - & + & + & - & + & - & + & - \\
\hline $40{ }^{\circ} \mathrm{C}$ & + & - & + & - & - & - & - & - \\
\hline $1 \% \mathrm{NaCl}$ & + & + & + & - & + & + & + & + \\
\hline $8 \% \mathrm{NaCl}$ & + & - & $\mathrm{ND}$ & + & + & + & - & + \\
\hline $9 \% \mathrm{NaCl}$ & + & - & $\mathrm{ND}$ & - & - & + & - & + \\
\hline Nitrate reduction to nitrite & + & - & + & - & - & - & - & - \\
\hline Nitrite reduction to nitrogen & - & + & - & - & - & - & - & - \\
\hline \multicolumn{9}{|l|}{ Hydrolysis of: } \\
\hline Gelatin & - & + & + & - & - & - & - & + \\
\hline Tween 80 & - & - & + & - & - & - & - & - \\
\hline \multicolumn{9}{|l|}{ Production of: } \\
\hline Valine arylamidase & + & - & + & - & $\mathrm{ND}$ & $\mathrm{ND}$ & ND & ND \\
\hline Acid phosphatase & + & + & + & - & $\mathrm{ND}$ & $\mathrm{ND}$ & $\mathrm{ND}$ & $\mathrm{ND}$ \\
\hline Naphthol-AS-BI-phosphohydrolase & + & + & - & - & $\mathrm{ND}$ & $\mathrm{ND}$ & ND & ND \\
\hline$\alpha$-Galactosidase & + & - & - & - & ND & ND & ND & ND \\
\hline$\beta$-Galactosidase & + & - & + & - & $\mathrm{ND}$ & $\mathrm{ND}$ & ND & ND \\
\hline Lysine decarboxylase & - & + & $\mathrm{ND}$ & - & $\mathrm{ND}$ & $\mathrm{ND}$ & ND & ND \\
\hline Ornithine decarboxylase & - & + & $\mathrm{ND}$ & - & ND & ND & ND & ND \\
\hline \multicolumn{9}{|l|}{ Utilization of: } \\
\hline Glycerol & + & + & + & + & + & + & - & - \\
\hline D-Ribose & - & + & + & + & + & $\mathrm{ND}$ & $\mathrm{ND}$ & - \\
\hline D-Xylose & + & + & ND & - & + & + & $\mathrm{ND}$ & - \\
\hline D-Glucose & + & + & + & + & + & + & - & + \\
\hline D-Fructose & + & - & + & + & + & + & - & + \\
\hline D-Mannitol & + & - & + & + & + & + & $\mathrm{ND}$ & - \\
\hline D-Sorbitol & + & - & + & + & + & + & - & - \\
\hline D-Cellobiose & + & - & $\mathrm{ND}$ & - & + & + & - & - \\
\hline Sucrose & + & - & + & + & + & + & $\mathrm{ND}$ & - \\
\hline Trehalose & + & - & - & $\mathrm{ND}$ & + & + & - & + \\
\hline Citrate & - & + & + & + & + & - & - & + \\
\hline Succinate & - & + & + & + & + & + & - & - \\
\hline L-Arginine & - & + & + & + & + & + & $\mathrm{ND}$ & + \\
\hline Pyruvate & - & ND & + & + & + & ND & - & + \\
\hline
\end{tabular}


pyruvate (Table 2). Apart from these characteristics, the strain can be further differentiated from its closest relative Thalassobius aestuarii $\mathrm{JC} 2049^{\mathrm{T}}$ by its ability to grow at $8 \%$ $\mathrm{NaCl}$, produce valine arylamidase, $\alpha$ - and $\beta$-galactosidases and to utilize D-fructose, D-mannitol, D-sorbitol, Dcellobiose, sucrose and trehalose as sole carbon sources and its inability to grow at $4{ }^{\circ} \mathrm{C}$, to reduce nitrite to nitrogen, to hydrolyse gelatin, to produce lysine decarboxylase and ornithine decarboxylase and to utilize D-ribose. It also differs from other close relatives by a number of phenotypic characteristics as shown in Table 2. Based on the phylogenetic evidence and chemotaxonomic and phenotypic characteristics presented in this study, we suggest that strain UST050418-052 ${ }^{\mathrm{T}}$ represents a novel member in the Roseobacter clade and propose the name Thalassococcus halodurans gen. nov., sp. nov.

\section{Description of Thalassococcus gen. nov.}

Thalassococcus (Tha.las.so.coc'cus. Gr. n. thalassa the ocean; L. n. coccus from Gr. n. kokkos berry, coccus; N.L. masc. n. Thalassococcus coccus from the ocean).

Cells are Gram-negative, ovoid-shaped, non-pigmented, devoid of swimming and gliding motility, strictly aerobic and halophilic. Oxidase- and catalase-positive. The major respiratory quinone is ubiquinone Q-10. The major fatty

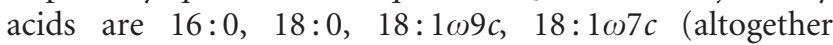
representing $82.9 \%$ of the total in the type strain of the type species) and summed feature $5(18: 2 \omega 6,9 c$ and/or anteiso-18:0). Phylogenetic analysis based on 16S rRNA gene sequences suggests that Thalassococcus is a member of the Roseobacter clade in the family Rhodobacteraceae. The genus currently contains one species, Thalassococcus halodurans, the type species.

\section{Description of Thalassococcus halodurans sp. nov.}

Thalassococcus halodurans (ha.lo.du'rans. Gr. n. hals salt, L. part. pres. durans withstanding, N.L. part. adj. halodurans withstanding salt).

Exhibits the following properties in addition to those given in the genus description. Cells are $0.7-1.0 \mu \mathrm{m}$ in diameter and colonies are milky, $1.1-1.4 \mathrm{~mm}$ in diameter, raised and circular with a smooth surface and an entire edge when cultivated on marine agar at $28{ }^{\circ} \mathrm{C}$ for $48 \mathrm{~h}$. Cells do not produce flexirubin-type or diffusible pigments. Growth occurs at pH $6-10$ and $12-44{ }^{\circ} \mathrm{C}$, with optimal growth at $28-36{ }^{\circ} \mathrm{C}$; no growth below pH 5 or at 4 or $52{ }^{\circ} \mathrm{C}$. Cells require a minimum of $2.0 \% \mathrm{NaCl}$ for growth and tolerate up to $18.0 \% \mathrm{NaCl}$ (optimum growth at 2.0-6.0\%). The DNA G + C content is $58.8 \mathrm{~mol} \%$. Cells are susceptible to $1.0 \mu \mathrm{g}$ benzylpenicillin, chloramphenicol and ampicillin, $5.0 \mu \mathrm{g}$ kanamycin and tetracycline and $10.0 \mu \mathrm{g}$ streptomycin. Does not hydrolyse starch, casein, chitin, cellulose, agar, gelatin or Tween 20,40 or 80 . Acetoin is produced but not indole or $\mathrm{H}_{2} \mathrm{~S}$. Nitrate is reduced to nitrite but not to nitrogen gas. Citrate is not utilized. Positive for activities of DNase, alkaline phosphatase, esterase $\left(\mathrm{C}_{4}\right)$, esterase lipase $\left(\mathrm{C}_{8}\right)$, leucine arylamidase, valine arylamidase, acid phosphatase, naphthol-AS-BI-phosphohydrolase, $\alpha$ - and $\beta$ galactosidases, $\alpha$ - and $\beta$-glucosidases and arginine dihydrolase. Negative for activities of urease, lipase $\left(C_{14}\right)$, cystine arylamidase, trypsin, $\alpha$-chymotrypsin, $\beta$-glucuronidase, $N$-acetyl- $\beta$-glucosaminidase, $\alpha$-mannosidase, $\alpha$-fucosidase, lysine decarboxylase, ornithine decarboxylase and tryptophan deaminase. Utilizes glycerol, D-glucose, sucrose, D-mannitol, D-galactose, starch, D-sorbitol, Darabinose and D-melibiose as sole carbon sources on agar medium supplemented with $4 \%(\mathrm{w} / \mathrm{v})$ carbon source, glycerol, L-arabinose, D-xylose, D-galactose, D-glucose, D-fructose, inositol, D-mannitol, D-cellobiose, maltose, Dmelibiose, sucrose, trehalose and potassium 2-ketogluconate in the API $50 \mathrm{CH}$ system and D-sorbitol in the MicroLog 3 system. Utilization of other carbon sources included in the MicroLog 3, API $20 \mathrm{NE}$ and $50 \mathrm{CH}$ systems is not observed. Acid is produced from glycerol, Larabinose, D-xylose, D-galactose, D-glucose, D-fructose, inositol, D-mannitol, D-sorbitol, D-melibiose, sucrose, Dfucose and potassium 2-ketogluconate in API $50 \mathrm{CH}$, but no acid production is observed in the API $20 \mathrm{E}$ system.

The type strain is UST050418-052 ${ }^{\mathrm{T}} \quad\left(=\mathrm{JCM} 13833^{\mathrm{T}}\right.$ $=$ NRRL B- $41465^{\mathrm{T}}$ ), isolated from the surface of the marine sponge Halichondria panicea collected from Friday Harbor, San Juan Island, WA, USA.

\section{Acknowledgements}

The authors thank Professor Dr Hans G. Trüper (University of Bonn, Germany) for generous help in Latin etymology. This work was supported by grants from the Research Grants Council of Hong Kong (CA04/05.Sc01 and HKUST6240/04M) to P.-Y.Q.

\section{References}

Acar, J. F. (1980). The disc susceptibility test. In Antibiotics in Laboratory and Medicine, pp. 24-54. Edited by V. Lorian. Baltimore: Williams \& Wilkins.

Allgaier, M., Uphoff, H., Felske, A. \& Wagner-Döbler, I. (2003). Aerobic anoxygenic photosynthesis in Roseobacter clade bacteria from diverse marine habitats. Appl Environ Microbiol 69, 5051-5059.

Arahal, D. R., Macián, E. G. \& Pujalte, M. J. (2005). Thalassobius mediterraneus gen. nov., sp. nov., and reclassification of Ruegeria gelatinovorans as Thalassobius gelatinovorus comb. nov. Int J Syst Evol Microbiol 55, 2371-2376.

Baumann, P. \& Baumann, L. (1981). The marine gram-negative eubacteria: genera Photobacterium, Beneckea, Alteromonas, Pseudomonas and Alcaligenes. In The Prokaryotes, vol. 1, pp. 13021331. Edited by M. P. Starr, H. Stolp, H. G. Trüper, A. Balows \& H. Schlegel. Berlin: Springer.

Bowman, J. P. (2000). Description of Cellulophaga algicola sp. nov., isolated from the surfaces of Antarctic algae, and reclassification of Cytophaga uliginosa (ZoBell and Upham 1944) Reichenbach 1989 as Cellulophaga uliginosa comb. nov. Int J Syst Evol Microbiol 50, 1861-1868. 
Buchan, A., González, J. M. \& Moran, M. A. (2005). Overview of the marine Roseobacter lineage. Appl Environ Microbiol 71, 5665-5677.

Cho, J. C. \& Giovannoni, S. J. (2004). Oceanicola granulosus gen. nov., sp. nov. and Oceanicola batsensis sp. nov., poly- $\beta$-hydroxybutyrateproducing marine bacteria in the order 'Rhodobacterales'. Int J Syst Evol Microbiol 54, 1129-1136.

Collins, M. D. (1994). Isoprenoid quinones. In Chemical Methods in Prokaryotic Systematics, pp. 265-310. Edited by M. Goodfellow \& A. G. O’Donnell. Chichester: Wiley.

Ezaki, T., Hashimoto, Y. \& Yabuuchi, E. (1989). Fluorometric deoxyribonucleic acid-deoxyribonucleic acid hybridization in microdilution wells as an alternative to membrane filter hybridization in which radioisotopes are used to determine genetic relatedness among bacterial strains. Int J Syst Bacteriol 39, 224-229.

Felsenstein, J. (1981). Evolutionary trees from DNA sequences: a maximum likelihood approach. J Mol Evol 17, 368-376.

Fitch, W. M. (1971). Toward defining the course of evolution: minimum change for a specific tree topology. Syst Zool 20, 406-416.

Giovannoni, S. J. \& Rappé, M. (2000). Evolution, diversity, and molecular ecology of marine prokaryotes. In Microbial Ecology of the Oceans, pp. 47-84. Edited by D. L. Kirchman. New York: Wiley.

Isnansetyo, A. \& Kamei, Y. (2003). Pseudoalteromonas phenolica sp. nov., a novel marine bacterium that produces phenolic antimethicillin-resistant Staphylococcus aureus substances. Int J Syst Evol Microbiol 53, 583-588.

Lau, S. C. K., Tsoi, M. M. Y., Li, X., Plakhotnikova, I., Wu, M., Wong, P. K. \& Qian, P. Y. (2004). Loktanella hongkongensis sp. nov., a new member of the $\alpha$-Proteobacteria originating from marine biofilms in Hong Kong waters. Int J Syst Evol Microbiol 54, 2281-2284.

Ludwig, W., Strunk, O., Westram, R., Richter, L., Meier, H., Yadhukumar, Buchner, A., Lai, T., Steppi, S. \& other authors (2004). ARB: a software environment for sequence data. Nucleic Acids Res 32, 1363-1371.

MacDonell, M. T., Singleton, F. L. \& Hood, M. A. (1982). Diluent composition for use of API $20 \mathrm{E}$ in characterizing marine and estuarine bacteria. Appl Environ Microbiol 44, 423-427.

Martens, T., Heidorn, T., Pukall, R., Simon, M., Tindall, B. J. \& Brinkhoff, T. (2006). Reclassification of Roseobacter gallaeciensis RuizPonte et al. 1998 as Phaeobacter gallaeciensis gen. nov., comb. nov., description of Phaeobacter inhibens sp. nov., reclassification of Ruegeria algicola (Lafay et al. 1995) Uchino et al. 1999 as Marinovum algicola gen. nov., comb. nov., and emended descriptions of the genera Roseobacter, Ruegeria and Leisingera. Int J Syst Evol Microbiol 56, 1293-1304.

Martínez-Cánovas, M. J., Quesada, E., Martínez-Checa, F., del Moral, A. \& Béjar, V. (2004). Salipiger mucescens gen. nov., sp. nov., a moderately halophilic, exopolysaccharide-producing bacterium isolated from hypersaline soil, belonging to the $\alpha$-Proteobacteria. Int $J$ Syst Evol Microbiol 54, 1735-1740.

Mesbah, M., Premachandran, U. \& Whitman, W. B. (1989). Precise measurement of the $\mathrm{G}+\mathrm{C}$ content of deoxyribonucleic acid by highperformance liquid chromatography. Int J Syst Bacteriol 39, 159-167.
Minnikin, D. E., O'Donnell, A. G., Goodfellow, M., Alderson, G., Athayle, M., Schaal, A. \& Parlett, J. H. (1984). An integrated procedure for the extraction of bacterial isoprenoid quinones and polar lipids. J Microbiol Methods 2, 233-241.

Nedashkovskaya, O. I., Kim, S. B., Hans, S. K., Lysenko, A. M., Rohde, M., Zhukova, N. V., Falsen, E., Frolova, G. M., Mikhailov, V. V. \& Bae, K. S. (2003). Mesonia algae gen. nov., sp. nov., a novel marine bacterium from the green alga Acrosiphonia sonderi (Kütz) Konm. Int J Syst Evol Microbiol 53, 1967-1971.

Neu, B., Voigt, A., Mitlohner, R., Leporatti, S., Gao, C. Y., Donath, E., Kiesewetter, H., Möhwald, H., Meiselman, H. J. \& Bäumler, H. (2001). Biological cells as templates for hollow microcapules. $J$ Microencapsul 18, 385-395.

Norris, J. R., Ribbons, D. W. \& Varma, A. K. (editors) (1985). Methods in Microbiology, vol. 18. London: Academic Press.

Ruiz-Ponte, C., Cilia, V., Lambert, C. \& Nicolas, J. L. (1998). Roseobacter gallaeciensis sp. nov., a new marine bacterium isolated from rearings and collectors of the scallop Pecten maximus. Int J Syst Bacteriol 48, 537-542.

Saitou, N. \& Nei, M. (1987). The neighbor-joining method: a new method for reconstructing phylogenetic trees. Mol Biol Evol 4, 406-425.

Schaefer, J. K., Goodwin, K. D., McDonald, I. R., Murrell, J. C. \& Oremland, R. S. (2002). Leisingera methylohalidivorans gen. nov., sp. nov., a marine methylotroph that grows on methyl bromide. Int J Syst Evol Microbiol 52, 851-859.

Shiba, T. (1991). Roseobacter litoralis gen. nov., sp. nov., and Roseobacter denitrificans sp. nov., aerobic pink-pigmented bacteria which contain bacteriochlorophyll a. Syst Appl Microbiol 14, 140-145.

Smibert, R. M. \& Krieg, N. R. (1994). Phenotypic characteristics. In Methods for General and Molecular Biology, pp. 607-654. Edited by P. Gerhardt, R. G. E. Murray, W. A. Wood \& N. R. Krieg. Washington, DC: American Society for Microbiology.

Uchino, Y., Hirata, A., Yokota, A. \& Sugiyama, J. (1998). Reclassification of marine Agrobacterium species: proposals of Stappia stellulata gen. nov., comb. nov., Stappia aggregata sp. nov., nom. rev., Ruegeria atlantica gen. nov., comb. nov., Ruegeria gelatinovora comb. nov., Ruegeria algicola comb. nov., and Ahrensia kieliense gen. nov., sp. nov., nom. rev. J Gen Appl Microbiol 44, 201-210.

Van Trappen, S., Mergaert, J. \& Swings, J. (2004). Loktanella salsilacus gen. nov., sp. nov., Loktanella fryxellensis sp. nov. and Loktanella vestfoldensis sp. nov., new members of the Rhodobacter group, isolated from microbial mats in Antarctic lakes. Int J Syst Evol Microbiol 54, 1263-1269.

Wagner-Döbler, I., Rheims, H., Felske, A., El-Ghezal, A., FladeSchröder, D., Laatsch, H., Lang, S., Pukall, R. \& Tindall, B. J. (2004). Oceanibulbus indolifex gen. nov., sp. nov., a North Sea alphaproteobacterium that produces bioactive metabolites. Int J Syst Evol Microbiol 54, 1177-1184.

Yi, H. \& Chun, J. (2006). Thalassobius aestuarii sp. nov., isolated from tidal flat sediment. J Microbiol 44, 171-176. 